\title{
Board Diversity and Firm Performance: Malaysia Context
}

\author{
Mohd Waliuddin Mohd Razali, Nursyuhada Abdul Aziz and Janifer Lunyai \\ Faculty Economics and Business, Universiti Malaysia Sarawak (UNIMAS)
}

\begin{abstract}
The large firms like Enron, WorldCom and Freddie Mac were involved in the crisis and the bankruptcy of corporate frauds and accounting scandals which were lack of effectiveness of their board of directors in those firms. Great board diversity will affect the firm performances in term of return on asset (ROA) and return of equity (ROE). This research used data of 385 samples of annual reports listed companies in Bursa Malaysia for the period of 2014 to 2016 were obtained and examined. The independent variables of board diversities are women in the board, board size, boards' educational level and the boards' experiences and control variables; firm size and firm leverage. After controlling the variables, the research shows only female has negatively significant towards ROE. It is because the number of female in board is very small. It also can be concluded that women have no power in board which the needed of them in making decision is low. For the control variables, firm size has positively significant towards ROA and ROE. Then, the firm financial leverage has a negatively significant towards ROA and ROE. For the future research, researchers are recommended for use other variables for board diversity such as board age and board independent and also use a long period of research such as for 5 to 10 years.
\end{abstract}

Keywords: board diversity, firm performance, Malaysia

\section{INTRODUCTION}

Nowadays, most of countries have been force or encourage with board diversity based on the policy that have been implemented. They have been confused whether that policy is affective for them or not. As we know, Malaysia is one of the countries that have to face this kind of policies. Hence, in today's business entities, employees and top management teams turn out to be more diverse especially in age, ethnicity, and gender, experience, educational background, and socioeconomic status.

The topic of the board diversified is not a new issue especially when scandals happened in the company like Malaysia Airlines and Port Klang Free Zone but it has been discussed and starting to get concerned from various parties. A good structure of the board of director of firms can give the best impact to the company's performance. Besides, many companies are competing with each other to get a good title for their companies.

There are many variables that presence in this research. One of it is the female board members. There are different opinions on the presence of women in the board with the firm performance. Some said that they support the presence of female in the board will give a good impact and some are not. There is a view from Hurst et al. (1989) and Earley and Mosakowski (2000) found that women are well to have "sense" cognitive style that concentrate on harmony and capability to simplify distribution of data. Otherwise, there are perspectives that the presence of female in the board would arise some difficulties to an organization. This can be concluded by looking from some views like Jackson et al (2003) where the larger the diversity, the higher the probability of conflicts would be arising, slow decision-making process (Hambrick et al., 1996), and differences in responding to risks (Jianakoplos and Bernasek, 1998). However, in Malaysia, starting 2011, there also stated that it must be $30 \%$ the representatives of women in the board have to be achieved which is better than Singapore due to the lot of work that must be done.

Besides that, there are some debates about the impact of size of board to the performance of firm in Malaysia. Today's era, there is important of corporate boards of director to understand the corporate governance hence they play the roles in the companies. This topic also has been discussed 
by the Lipton and Lorsch in 1992 and Jensen in 1993 where the performance of firms is declining effect from the lack of effectiveness on board of directors when they are suffering from coordination and communication problems. If the larger board size is the reason for the ineffectiveness of the firm, then the governance should improve them by doing some changes for the size of the board.

After that, the variable of boards' educational level in the firms is contributed for the relationship of the firm performance. The qualifications of the board members are very important for the contribution in the decision making. As there is an argued from Hilmer (1998) which the higher qualification of the board members can contribute for the effectiveness of board, which involves, "great of intellectual capability, experience, firmness of contemplation and integrity". Hence, the knowledge of the board of directors about the finance, accounting and so on is very important to measure the knowledge for organizing the firms in the correct ways.

In Malaysia, the age average of the board directors who have more experience in managing firms between higher age average and younger age average also has been debated. The higher age average is more towards sensitive in making decision compared to younger age who is more relax than them. This characteristic may give some impact in making decision that will affect the firm performance (Carlson \& Karlsson, 1970).

\section{LITERATURE REVIEW}

\section{Resources Dependency Theory}

The board directors are responsible by to monitor and control the internal of the firm while providing the resources. Pfeffer (1972) and Taljaard et al (2015) stated that to increase the firm performances and decrease uncertainty, the firms should have secure resources from the environment. Bryant \& Davis (2012) and Taljaard et al. (2015) also argued that a diverse board is better to securing the resources because it is good in accessing details and connections. This theory also assists to have the access to the financial resources. There is also the relation between borrowing strategy of firms and types of financial representation on board as such relationships which provide them with a chance to co-opt each other on a continuous. Due to the different of background, skills, experiences and social networks, the diversified on the board may increase the performance of the board in the company.

\section{Human Capital Theory}

Gary S. Becker and Mincer (1958) said that other things are equal, but the personal incomes are different according to the amount of the investment in human capital which are the education and training that have been taken by individuals or groups of employees. Hillman \& Dalziel (2003) view that the effectiveness in monitoring and resources provision roles is depends on the skill and knowledge of the board members. Human capital can be a part from board members' knowledge and skill. Thus, this human capital theory says that the unique human capital in the board of director as an example of board diversity give effect to the firm performance (Carter et al., 2010). So, from here we can argue that the board diversity positively influences the firm performance.

\section{Firm Performance}

Arend (2004) said that all firms want to build the greatest performance among the firms in the same industry. But, there are many view of performance especially among the firms and the researcher. The most common firm performance indicator is by using the accounting measure of profitability for the financial performance of the companies. But besides the firm performance indicator, there also another indicators of firm performances which are the satisfaction of customers, employee satisfaction, performance of social and performance of the environmental (Combs et al., 2005). The most common indicator of firm performance is the financial performance like return on equity (ROE) and return on assets (ROA) which is refers to the capability of firm to make the profit or income. The 
financial performance side includes the measurement for the ROA, ROE, return on investments, net income, earnings before interest, and others.

\section{Board Diversity and Firm Performance}

According to Kahn (2002), diversity means as dissimilarities in the factual form of the word but the term has been converted to a determined strategic path where changes are considered to be important and beneficial. The diversity also is categories in terms of gender, age, ethnicity, physical look, beliefs, job role or experience, incapacity, individual manner and belief. The diverse group in the firm especially in term of board directors can increase the competitiveness as come out with the great ideas and view point that available for the decision making need as well as can invite a greater number of shareholders and employees and help in maintaining the current while potentially increase new minority consumers (Cox, 1993).

Nowadays in fast of worldwide market, diversified include dissimilarities in age, culture, gender, abilities in bodily view, sexual orientation and qualities as good as variation in attitudes, perceptions and background. Pfeffer (1972) and Pfeffer and Salincik (1978) also argued based on the resource dependence theory, directors that come from different place can contribute to gather more information and resources from their own place for their own organization.

\section{Hypothesis Development}

\section{Gender}

There a lots of perspective on the relationship between gender diversity and performance of firms. Some arguments support relationship between gender diversity and firm performance in positive view due to various reasons. For instance, the relationship between presence of female on board and financial performance in terms of ROA is positive and significant (Abdullah, Ismail, Nachum, 2013). Next, the study from Netherlands give a view where the ROE show a good performance for firm that have women directors that a firm that have no women director in their organization (LückerathRovers, 2011). There is a view which is argued that gender diversity will help in leading for more creativity and innovation in a firm (Campbell and Minguez-Vera, 2008). In addition, female board members commonly have well in understanding of a market compared to the male board members. Hence, this will help the firm to have a good and efficient in decision making by the board members. So, the presence of female board members in a firm actually gives positive impact either in directly or indirectly for the firm performance. Therefore,

$\mathrm{H}_{1}$ : there is positive relationship between female board members and firm's performance.

\section{Board Size}

Refers to the Levrau and Van Den Berghe (2007) board size means the amount of directors sitting on the board. Greater boards are good for the board performance because they possess vary of skill to help in decision making and tougher for a powerful CEO to control. Board size always becomes a topic to discuss when it relates to the firm performance. If the board is too big, the management will face a situation when they are hard to be organizing and development difficulties will arise. However, minor boards will help to decrease the free riders and can raise the accountability of the individual and the directors. For example, there is a study by De Andres and Vallelado (2008) argued that a larger board are more efficient in monitoring and advise the function and increase more value for a firm. Besides, board sizes are positively influence the ROA (Shukeri et al., 2012). Unfortunately, some researchers provide the evidence which is said that there is a negative relationship between the size of board and the firm performance. One of it is Beiner et al. (2004) revealed that there is a negative board size effect in the relationship between board size and the independent corporate governance mechanism of Swiss firms. Therefore, 
$\mathrm{H}_{2}$ : there is a negative relationship between board size and firm performance.

\section{Boards' Educational Level}

In a company, one of the internal corporate governance is the role of a board. Fama and Jensen (1983) also said that board in a business act as control system. As a group of board members, they are combination of skills and abilities that together symbolize a group of social capital, and add value in performing the board's governance function (Carpenter \& Westphal, 2001). The efficient in supervising and monitoring in management and making decision by the directors will increase the performance of the firms. A higher educational level has a positive effect on the performance of the firms. This is because the educational level gives important human capital for an effective performance of the tasks of board members (Arena et al., 2015). Besides, from the view of Carpenter \& Westphal (2001) and Carver (2002) argued that the board members with higher qualifications will benefits the firms through a mix competencies and capabilities. Based on this argument, it is clear that directors' educational qualification and their specialisations are important in contribute to the firm performance. Therefore,

$\mathrm{H}_{3}$ : there is positive relationship between the boards' educational level and firms' performance.

\section{Boards' Experiences}

Board directors must have experience and making decision also needs experiences in order to be selected on the board. There is an argued where the board members with a higher age average will have much better experience than the younger age average in corporate board. In Malaysia, most of board directors have less than nine years' board experience (Securities Commission Malaysia, 2011). The experience that the board members have is estimated to positively contribute to the better and efficient of the performance of a firm. Although the view of the relationship between the boards' educational level and firm performance has some conflict but a theory on restrained resources said that the more experiences of the board members will manage better in a business environment by working well in a group which is give a positive effect to the firm's performance (Wegge et al., 2008). Furthermore, Wan Yusoff (2010) found that experience in corporate management is an integral part of the effectiveness of Public Listed Company (PLC) boards. Besides, there is a relationship between firm performance and directors' seniority. Therefore,

$\mathrm{H}_{4}$ : there is positive relationship between the boards' experience and firms' performance.

\section{METHODOLOGY}

\section{Sample}

Sample has been chosen from companies listed in Bursa Malaysia's Main Board. There are 8 industries in the market. The samples selected are companies that are involved in industrial products industry, constructions, consumer products, plantation, properties, and trading and services. In this study, board diversified disclosure is the main focus for evaluation. The period of sample taken is 3 years beginning from 2014 to 2016. This study proposes to examine 395 companies' annual reports in the industrial products industry, constructions, consumer products, plantation, properties, and trading and services for 3 years. From table 2 below, the initial sample of this study was 395 companies in the industrial products industry. However, some of these companies did not have the complete data required. Hence, from the initial sample, only 385 companies in the industrial products industry had the complete information needed for this study. Therefore, 10 companies in the industrial products industry have been taken out from the initial sample. The financial measures of the firm monetary performance fit into accounting-based measures. In this study, the return on asset (ROA) and return on equity (ROE) are used to determine the firm performance. ROA is calculate using the earnings before tax and interest divide by the total assets while the ROE using the net profit (after interest and taxes) divide by average common shareholders' equity. 


\section{Regression Model}

The multiple regression analysis is used to observe the relationship between the firm performance and independent variable and control variables. The model attempts to capture the factors that are likely to be important in influencing the firm performance.

$\mathrm{PERF}=\alpha$ (female board, board size, educational level, experience)

Hence our function can be estimated under the following model:

PERF $=\alpha+\beta_{1}$ FEMALE $_{i, \mathrm{t}}+\beta_{2}$ SIZE $_{\mathrm{i}, \mathrm{t}}+\beta_{3} \mathrm{EDU}_{\mathrm{i}, \mathrm{t}}+\beta_{4} \mathrm{EXPR}_{\mathrm{i}, \mathrm{t}}+\beta_{5} \mathrm{SFIRM}_{\mathrm{i}, \mathrm{t}}+\beta_{6} \mathrm{FLEV}_{\mathrm{i}, \mathrm{t}}+\varepsilon_{\mathrm{i}, \mathrm{t}}$

Where:

\begin{tabular}{|c|c|}
\hline PERF & $=$ Firm performance \\
\hline$\alpha$ & $=$ Constant \\
\hline$\beta$ & $=$ Coefficient \\
\hline FEMALE & $=$ Number of female present on the board \\
\hline SIZE & $=$ Number of board members \\
\hline EDU & $=$ Educational qualification heterogeneity \\
\hline EXPR & $=$ Board's working experience \\
\hline SFIRM & $=$ Natural logarithm of book value of total assets \\
\hline FLEV & $=$ Ratio of total debt divided by equity \\
\hline$\varepsilon$ & $=$ Standard normal, randomly assigned error term \\
\hline i & $=$ companies \\
\hline $\mathrm{t}$ & $=$ time \\
\hline
\end{tabular}

Measurements of Dependent Variables

Table 1: List of the variables being used in this study

\begin{tabular}{|c|c|c|c|}
\hline Variables & Description & Source & Measurement \\
\hline $\begin{array}{l}\text { Return on asset } \\
\text { (ROA) }\end{array}$ & $\begin{array}{l}\text { Net income (Earnings } \\
\text { Before Tax and } \\
\text { Interest)/Total Assets }\end{array}$ & $\begin{array}{l}\text { Shrader et al. (1997) and } \\
\text { Erhardt et al. (2003) }\end{array}$ & $\begin{array}{l}\text { Net income divided by } \\
\text { Total Assets }\end{array}$ \\
\hline $\begin{array}{l}\text { Return on equity } \\
\text { (ROE) }\end{array}$ & $\begin{array}{l}\text { net income (after interest } \\
\text { and taxes) divided by } \\
\text { average common } \\
\text { shareholders' equity }\end{array}$ & $\begin{array}{l}\text { Phan et al. (2003); Baek } \\
\text { et al. (2004) }\end{array}$ & $\begin{array}{l}\text { Net income divided by } \\
\text { shareholder's equity }\end{array}$ \\
\hline $\begin{array}{ll}\begin{array}{l}\text { Female } \\
\text { members }\end{array} & \text { board } \\
\end{array}$ & Dummy variables & $\begin{array}{l}\text { Carter et al. (2003), } \\
\text { Adams \& Ferreira (2002) }\end{array}$ & $\begin{array}{l}\text { Using the dummy } \\
\text { variables }\end{array}$ \\
\hline Board size & $\begin{array}{l}\text { Log of number of } \\
\text { directors }\end{array}$ & $\begin{array}{l}\text { Yermack (1996), Carter et } \\
\text { al. (2003), Mak \& Li } \\
(2001)\end{array}$ & $\begin{array}{l}\text { Natural log of number } \\
\text { of directors }\end{array}$ \\
\hline $\begin{array}{l}\text { Boards' } \\
\text { Educational level }\end{array}$ & $\begin{array}{l}\text { Log of Phd present on } \\
\text { board }\end{array}$ & Bathula, (2008) & $\begin{array}{l}\text { Natural logarithm of } \\
\text { PhD present on the } \\
\text { board after adding } 1 \text { to } \\
\text { all firms }\end{array}$ \\
\hline $\begin{array}{l}\text { Boards' } \\
\text { Experience }\end{array}$ & Average age of directors & 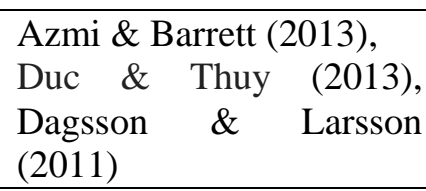 & $\begin{array}{l}\text { Annual report year } \\
\text { minus birth year }\end{array}$ \\
\hline Firm size & Log of total asset & Maran \& Indraah (2009) & Natural log of total asset \\
\hline $\begin{array}{l}\text { Firm's financial } \\
\text { leverage }\end{array}$ & $\begin{array}{l}\text { Ratio of the total debt of } \\
\text { the firm divide by its } \\
\text { shareholder equity }\end{array}$ & $\begin{array}{ll}\text { Chaganti } & \text { \&Damanpour } \\
\text { (1991), Muth \& } \\
\text { Donaldson } & (1998)\end{array}$ & $\begin{array}{l}\text { Total debt divide by } \\
\text { shareholder's equity }\end{array}$ \\
\hline
\end{tabular}




\section{RESULTS AND DISCUSSION}

\section{Descriptive Statistics}

The samples in this study enclosed 385 companies listed on Bursa Malaysia, annual report for the year 2014 to 2016 were collected and analysed. Descriptive statistic data employed in the analysis are shown above in the Table 2. The table shows the minimum, maximum, mean and standard deviation values for all variables.

The firm performance in term of return on asset (ROA) is measured by using the net income divided by the total assets. An analysis of Table 2 shown that the average of return on assets (ROA) for the sample companies in 2014 to 2016 is $5.24 \%$ (range from $-14.55 \%$ to $57.35 \%$ ) with the gap between the minimum and maximum score is quite high for them. The standard deviation figure was $6.09 \%$. Next, the firm performance is defined by the return on equity (ROE) which is measure by using the net income divided by the shareholders' equity. Based on the table, it reveals that the average of return on equity is $7.71 \%$ (range from $-28.00 \%$ to $85.16 \%$ ). From the samples of the study, the standard deviation also lies on $10.77 \%$.

Table 2: Descriptive statistic of the variables

\begin{tabular}{lccccc}
\hline & $\mathrm{N}$ & Minimum & Maximum & Mean & Std. Deviation \\
\hline ROA & 385 & -14.5500 & 57.3500 & 5.2399 & 6.0906 \\
ROE & 385 & -28.0000 & 85.1600 & 7.7124 & 10.7716 \\
FEMALE & 385 & 0.0000 & 50.0000 & 1.6946 & 6.2573 \\
BSIZE & 385 & 4.0000 & 14.0000 & 7.4753 & 1.9112 \\
EDU & 385 & $0 \%$ & $100 \%$ & $29.61 \%$ & $25.63 \%$ \\
EXPR & 385 & 36.5600 & 74.6000 & 57.7774 & 4.7706 \\
FSIZE & 385 & 4.3657 & 8.1234 & 5.8456 & 0.6464 \\
FLEV & 385 & 0.0000 & 7.0200 & 0.5449 & 0.6612 \\
\hline
\end{tabular}

One of the independent variables is the female board member represented by the FEMALE with the mean of $1.69 \%$ which is calculated by the total number of female present on the board to total number of board directors of the companies. The range of female with the lowest number of $0.00 \%$ and the highest number is $50.00 \%$. The standard deviation is $6.26 \%$. Next variable is board size which is represented by BSIZE with a mean of 7.48 people with the range from minimum of 4.00 people to maximum 14.00 people. The standard deviation figure was 1.91 . Then, the variable of boards' educational level is represented by EDU. EDU is measured by the total number of board member that hold postgraduate divided by the total number of board directors. The board educational level had an average of $29.61 \%$ (range from $0 \%$ to $100 \%$ ). The standard deviation figure was $25.53 \%$. Besides, the other variable is boards' experiences which are represented as EXPR on the Table 2. The table shows that the boards' experiences have mean of $57.78 \%$. The range is between $36.56 \%$ to $74.60 \%$. While the standard deviation is $4.78 \%$.

Another variable is control variables being used in this study are firm size and firm leverage. The firm size is represented as FSIZE. FSIZE is measured by $\log _{10}$ of the total asset with the average of 5.85 which indicate that most of companies in this sample were relatively small. The minimum and maximum for FSIZE were 4.37 and 8.12 respectively. The standard deviation of company size was 0.65 implies that the size of companies in Bursa Malaysia is quite varies. While the firm leverage (FLEVERAGE) has an average of 0.55 with between the range of 0.00 and 7.02. And the standard deviation is 0.66 .

\section{Pearson Correlation Coefficient}

Pearson correlation presented the correlation matrix of the variables used for a research. Besides, it is used as an estimation of the strength of the association and significant of bivariate connections among 
the variables. The ideal correlation between two variables is expressed by 1.0 while idealize negative correlation is expressed by -1.0 . Consequently, the correlation is range between -1.0 and +1.0 . According to Rummel (1976), the result of the correlation will vary among each other as the raw data inserted is different and the results are not expected to be the same. This proves that the higher the correlation, the higher the strength of the relationship between the variables.

Table 3: Correlation Analysis

\begin{tabular}{|c|c|c|c|c|c|c|c|c|}
\hline \multicolumn{9}{|l|}{$\begin{array}{l}\text { Correlation } \\
\text { Probahility }\end{array}$} \\
\hline ROA & 1.0000 & & & & & & & \\
\hline ROE & $\begin{array}{c}0.8894 * * * \\
0.0000\end{array}$ & 1.0000 & & & & & & \\
\hline FEMALE & $\begin{array}{c}-0.0280 \\
0.3681\end{array}$ & $\begin{array}{c}-0.0604 * \\
0.0522\end{array}$ & $\begin{array}{c}1.0000 \\
-----\end{array}$ & & & & & \\
\hline BSIZE & $\begin{array}{l}0.0330 \\
0.2886\end{array}$ & $\begin{array}{c}0.0655 * * \\
0.0352\end{array}$ & $\begin{array}{c}-0.0618^{* *} \\
0.0470\end{array}$ & $\begin{array}{c}1.0000 \\
----\end{array}$ & & & & \\
\hline EDU & $\begin{array}{l}0.0183 \\
0.5572\end{array}$ & $\begin{array}{c}-0.0174 \\
0.5760\end{array}$ & $\begin{array}{c}0.4422 * * * \\
0.0000\end{array}$ & $\begin{array}{c}-0.0684 * * \\
0.0279\end{array}$ & $\begin{array}{c}1.0000 \\
----\end{array}$ & & & \\
\hline EXPR & $\begin{array}{l}0.0108 \\
0.7300\end{array}$ & $\begin{array}{l}0.0275 \\
0.3767\end{array}$ & $\begin{array}{l}-0.0182 \\
0.7928\end{array}$ & $\begin{array}{l}0.0041 \\
0.8965\end{array}$ & $\begin{array}{l}0.0141 \\
0.6497\end{array}$ & $\begin{array}{c}1.0000 \\
-----\end{array}$ & & \\
\hline FSIZE & $\begin{array}{l}0.0115 \\
0.7128\end{array}$ & $\begin{array}{c}0.0984 * * * \\
0.0016\end{array}$ & $\begin{array}{c}-0.0547^{*} \\
0.0790\end{array}$ & $\begin{array}{c}0.3732 * * * \\
0.0000\end{array}$ & $\begin{array}{l}-0.0056 \\
0.8585\end{array}$ & $\begin{array}{c}0.1683 * * * \\
0.0000\end{array}$ & $\begin{array}{c}1.0000 \\
----\end{array}$ & \\
\hline FLEV & $\begin{array}{c}-0.1573 * * * \\
0.0000\end{array}$ & $\begin{array}{l}0.0154 \\
0.6200\end{array}$ & $\begin{array}{c}-0.1233 * * * \\
0.0000\end{array}$ & $\begin{array}{c}0.1337 * * * \\
0.0000\end{array}$ & $\begin{array}{c}-0.1705^{* * *} \\
0.0000\end{array}$ & $\begin{array}{l}0.0082 \\
0.7928\end{array}$ & $\begin{array}{c}0.3863^{* * *} * \\
0.0000\end{array}$ & $\begin{array}{c}1.0000 \\
----\end{array}$ \\
\hline
\end{tabular}

Note: ***.Correlation is significant at the 0.01 level (1-tailed), **.Correlation is significant at the 0.05 level (1-tailed), and *. Correlation is significant at the level 0.10 (1-tailed).

Table 3 shows the result of the correlation between the independent variables, control variables and dependent variables on this research. It is describing the female board members (FEMALE), board size (BSIZE), educational level of board (EDU), working experience of board (EXPR), firm size (FSIZE) and firm leverage (FLEV) which are related to firm performance in term of return on asset (ROA) and return on equity (ROE) for the 395 companies in the Bursa Malaysia. The table also showed signs of positive and negative significant correlations among the independent variables and control variables.

As shown in the table 3, the result shows board size, educational level, experiences and firm size have a positive relationship towards ROA with $0.0330,0.0183,0.0108$ and 0.0115 . However, there are no significant towards ROA. The Pearson correlation coefficient between ROA and female board member (FEMALE) is -0.0280 which is there is negative and no significant relationship towards the firm performance in term of ROA. Besides, the table shows that the result between ROA and firm leverage (FLEV) is -0.1573 . It shows negative relationship and significant with the firm leverage at $1 \%$ level of significant. Hence, it can be concluding that ROA is increases as the firm leverage decreases.

Next, based on the Table 3 has shown those board size (BSIZE) and firm size (FSIZE) have both positive relationship and significant towards the firm performance in term of $\mathrm{ROE}(\mathrm{r}=0.0655$; $\mathrm{p}$ value $=0.0352$ and $\mathrm{r}=0.0984 ; \mathrm{p}$-value $=0.0016$ respectively). Board size is significance at $5 \%$ level of significant and firm size is at $1 \%$ level of significant. In contrast, ROE shows a negative relationship on female board member (FEMALE) and significance at $10 \%$ level of significant. Hence, this shows that female board members have not harm towards the firm performance in term of ROE. 
Besides, both boards' experiences (EXPR) and firm leverage (FLEV) shows a positive relationship but not significant related to ROE. Then, the results also show there is negative relationship but not significant between boards' educational level (EDU) and ROE. In conclusion, ROE is increases as well as board size and firm size increases while the number of female on the board is not harm the firm performance in term of ROE.

\section{Multiple Regression Analysis}

Multiple Linear Regressions is utilized to evaluate the variability in the extension of board diversity. This method will be able to indicate on how much the variance in the dependent variable is clarified by the independent variables.

Table 4: Regression Model Summary $1 \& 2$

\begin{tabular}{lll}
\hline & Model 1 (ROA) & Model 2 (ROE) \\
\hline R Square & 0.0356 & 0.0147 \\
Adjusted R- Square & 0.0301 & 0.0089 \\
Std. Error of The Estimate & 6.3337 & 10.7183 \\
\hline
\end{tabular}

As shown on the Table 4 indicates the influence of board diversity for female board members, size of board, boards' educational level and boards' experiences with the control variables; firm size and firm leverage have a value of $\mathrm{R}$ square 0.0356 . This implies that $3.56 \%$ of the variance for the ROA disclosure is accounted for by the four independent variables in the model. Adjusted R-square is computed to take into account of more observations. From the table above shows, the value of adjusted R-square is 0.0301 . It is shows that there are $3.01 \%$ of the variation in the ROA disclosure can be explained by the variation in the independent variables and control variables after the degree of freedom is taken into account.

The second model is the influence of board diversity; female, board size, boards' educational and boards' experiences with the control variables; firm size and firm leverage have a value of $\mathrm{R}$ square 0.0147 . This implies that $1.47 \%$ of the variance for the ROE disclosure is accounted for by the four independent variables in the model. Adjusted R-square is computed to take into account of more observations. From the table above shows, the value of Adjusted R-square is 0.0089. It is shows that there is only $0.89 \%$ of the variation in the ROE disclosure can be explained by the variation in the independent variables and control variables after the degree of freedom is taken into account.

\section{The Coefficient of Multiple Regression Analysis of ROA}

As shown in Table 5, the ANOVA statistic for regressions conducted with the independent variables and control variables indicate that the overall regression model was significant to the data. The reason why it is significant because of the reported probabilities were less than the conventional $0.01(1 \%)$ which is $0.0000<\mathrm{p}$-value. This shows that when all independent variables and control variables are good joint predictors of dependent variable of ROA. Based on ANOVA the F statistics is 6.4606. 
Table 5: The Coefficient of Multiple Regression Analysis of ROA

\begin{tabular}{lllll}
\hline Variable & Coefficient & Std. Error & t-Statistic & Prob. \\
\hline C & & & & \\
FEMALE & -0.403728 & 2.791632 & 0.144621 & 0.8850 \\
BSIZE & 0.0744530 & 0.034959 & -0.959124 & 0.3377 \\
EDU & -0.937871 & 0.849027 & -1.104642 & 0.2696 \\
EXPR & 0.008607 & 0.041274 & 0.208520 & 0.8349 \\
FSIZE & 0.855338 & 0.356628 & 2.398407 & 0.0166 \\
FLEV & -1.889535 & 0.312411 & -6.048231 & 0.0000 \\
& & & & \\
R-squared & 0.035636 & Mean dependent var & 5.067604 \\
Adjusted R-squared & 0.030120 & S.D. dependent var & 6.431272 \\
S.E. of regression & 6.333677 & Akaike info criterion & 6.536246 \\
Sum squared resid & 42081.12 & Schwarz criterion & 6.569139 \\
Log likelihood & -3444.138 & Hannan-Quinn criter. & 6.548714 \\
F-statistic & 6.460572 & Durbin-Watson stat & 1.325539 \\
Prob(F-statistic) & 0.000001 & & \\
\hline
\end{tabular}

$\begin{array}{cccccc}\mathrm{ROA} & =0.4037+(-0.0335) \mathrm{FEMALE}+ & +0.0745 \mathrm{BSIZE}+ & + & (-0.9379) \mathrm{EDU}+ \\ & 0.0086 \mathrm{EXPR}+0.8553 \mathrm{FSIZE}+(-1.8895) \mathrm{FLEV}\end{array}$

The first hypothesis 1 in this study is regarding the female board member. In this research, the female board member was hypothesized as there is a positive relationship with the firm performance in term of ROA. The coefficient for female is -0.0335 . From the table 5 , it shows that there is a negative relationship but not significant between female board member and ROA with the t-statistics is -0.9591 and $p$-value is 0.3377 . Therefore, the hypothesis is not supported. Then, it shows that the range number of female in board on the samples is small. This result is not consistent with the prior study where the findings show a positive relationship between gender and ROA which recommends women might give a better financial performance in the company (Julizaerma \& Sori, 2012). However, the result is not significant which is influenced by the small number of women director presented in board where there is no strong relationship between female board member and firm performance which is assumed that the number of female in the sample is very small. Besides, the lack involvement of women in board is due to the cultural and social attitudes towards a job which not every job woman can involve.

In addition, hypothesis 2 stated that there is negative relationship between board size and ROA. Based on the Table 5, the coefficient is 0.0745 and t-statistic is 0.6741 . Board size shows a positive relationship to ROA but not significant with the probability of 0.5004 . Therefore, the hypothesis is not supported. Besides, there also a previous research that support which is the board sizes are positively influence the ROA ( $\mathrm{Ng}$ et al., 2016). They also argue that the smaller board size leads to effective management while the larger size is important for coordination and effectiveness of decision making. Besides, board size with the average of eight give a high influence towards the performance of firm. Managers in the small firms can be very different in having strong, vested interests, both financial and emotional in the firms' performance.

Based on the Table 5, the result shows a negative insignificant relationship between boards' educational level to ROA. The coefficient of educational level of board is -0.9379 . The table also shows the educational level t-statistic is -1.1046 with the significant of 0.2696 . From these result, it 
shows that there is no strong evidence of a relationship between boards' educational level and firm performance and firms' ROA performance may be influenced by other board director's characteristic. This is aligned with the prior study which is there a negative relationship with firms' performances (Adnan, et al., 2016). They also found the education diversity in board looks important to the firms' culture that appointing successful directors in highlighting on the governance characteristics rather than education characteristics.

Next, the hypothesis 4 stated that there is a positive relationship between the boards' experience and firm performance. The coefficient of boards' experiences (EXPR) is 0.0086. The table also shows the boards' experiences has a positive insignificant relationship between firm performance by ROA which the t-statistic of 0.2085 and the level of significant of 0.8349 . Therefore, the hypothesis is not supported. So, it cannot be concluding that the experience of board members has a positively contribute to the better and efficient of the performance of a firm. This is not same with the prior study which boards' working experiences has a positive correlation with the firm performance (Duc \& Thuy, 2013). Therefore, experiences of boards are needed for the benefits of shareholders and the management of the firms which can contribute positively to firms' performance.

After that, the variable of firm size is use in this research which is there is a relationship towards firm performance in term of ROA. The coefficient for firm size (FSIZE) is 0.8553 . The table shows the firm size and ROA has a positive relationship which the t-statistic is 2.3984 and the significance is 0.0166 at the $5 \%$ level of significant. Therefore, the hypothesis is supported. It can be proved by the previous research which there is a positive influence between firms' size towards profitability (Lee, 2009). Besides, firm size plays an important role in explaining the performance of firm which they are able to diversity their risks. The positive sign of size with the higher profitability of firm can be influenced by the market power which a larger firm may have high market power and provides them an opportunity to charge higher prices and earn more profits.

Lastly hypothesis stated that there is a relationship between firm leverage and firm performance of ROA. The coefficient for firm leverage (FLEV) is -1.8895 . The table reveals that firm leverage has a negative relationship with ROA which is the t-statistic is -6.0482 and the significant is 0.0000 at the level of $1 \%$ level of significant. Therefore, the hypothesis is supported. This result is same as the previous study where the leverage has a significantly negative impact on firm performance when the firm size is low or small (Ibhagui \& Olokoyo, 2018). Furthermore, they found that it will give a negative effect decreasing as a firm grows and threatened when firm size exceeds its estimated level. Besides, most of the companies' capital structure are relies on short term debt and has a low amount of long term debt.

\section{The Coefficient of Multiple Regression Analysis of ROE}

As shown in Table 6, the ANOVA statistic for regressions conducted with the independent variables and control variables indicate that the overall regression model was significant to the data. The reason why it is significant because of the reported probabilities were less than the conventional $0.05(5 \%)$ which is $0.0187<\mathrm{p}$-value. This shows that when all independent variables and control variables are good joint predictors of dependent variable of ROE. Based on ANOVA the F statistics is 2.5494.

The hypothesis 1 in this study is regarding the female board member. In this research, the female board member was hypothesized as there is a positive relationship with the firm performance in term of return on asset (ROE). The coefficient for female board member (FEMALE) is -0.1046. From the table 6, it shows that there is a negative relationship and significance between female board member and ROE with the t-statistics is -1.7526 and p-value is 0.0800 at $10 \%$ level of significant. Therefore, the hypothesis is not supported. The result shows negative because the range of female on board in these samples is low. Besides, it can be concluding that female have no power in board especially in decision making. This is opposite with the previous study which found that there is a positively significant between female board member and ROE. Also, female give higher significantly for companies than for companies without female on the board (Lückerath-Rovers, 2010). Besides, 
the influence on the decisions made on the financial performance is hard to measure due to many factors affect the firms' performances. So, the presences of female in board is needed in decision making which can become more innovative, modern and transparent and give a high performance for the firms. They also show that the presences of female on board give a good impact for the performance of the firms especially in give a better connection among the stakeholders in all levels on the firms.

Table 6: Coefficient of Multiple Regression Analysis of ROE

\begin{tabular}{|c|c|c|c|c|}
\hline Variable & Coefficient & Std. Error & t-Statistic & Prob. \\
\hline $\mathrm{C}$ & -3.799808 & 4.778859 & -0.795129 & 0.4267 \\
\hline FEMALE & -0.104605 & 0.059687 & -1.752554 & 0.0800 \\
\hline BSIZE & 0.176453 & 0.189004 & 0.933594 & 0.3507 \\
\hline EDU & 0.267798 & 1.468288 & 0.182388 & 0.8553 \\
\hline EXPR & 0.024119 & 0.071204 & 0.338729 & 0.7349 \\
\hline FSIZE & 1.572205 & 0.611294 & 2.571929 & 0.0103 \\
\hline FLEV & -0.538621 & 0.558793 & -0.963900 & 0.3353 \\
\hline R-squared & 0.014675 & \multirow{6}{*}{\multicolumn{2}{|c|}{$\begin{array}{l}\text { Mean dependent var } \\
\text { S.D. dependent var } \\
\text { Akaike info criterion } \\
\text { Schwarz criterion } \\
\text { Hannan-Quinn criter. } \\
\text { Durbin-Watson stat }\end{array}$}} & 7.712186 \\
\hline Adjusted R-squared & 0.008919 & & & 10.76637 \\
\hline S.E. of regression & 10.71825 & & & 7.588519 \\
\hline Sum squared resid & 117982.6 & & & 7.621970 \\
\hline Log likelihood & -3916.264 & & & 7.601212 \\
\hline F-statistic & 2.549361 & & & 1.293388 \\
\hline Prob(F-statistic) & 0.018664 & & & \\
\hline
\end{tabular}

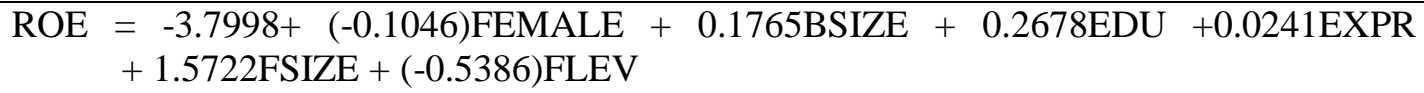

In addition, hypothesis 2 stated that there is negative relationship between board size (BSIZE) and ROE. The coefficient is 0.1765 and t-statistic is 0.9336 . Board size shows a positive relationship to ROE but not significant with the probability of 0.3507 . Therefore, the hypothesis is not supported. This result also same with the study in Turkey which found that there was a positively insignificant between board size and ROE with assume that board size is not influential on return on equity and market value of the firm (Topal \& Dogan, 2014). But, the diversity of board size towards profitability can be influence by the economics of scale. Large firms can have a benefit of lower cost which size give a bargaining power over the suppliers when produced a standardized product on a large quantity with the long runs in production so the large firm will be more efficient.

Besides, the hypothesis 3 on board educational level of board predicted that as the positive effect of board members that hold a postgraduate qualification will be more for firms with the larger board than the firm with the smaller firm to a good performance of firm. Based on the Table 6, the result shows a positive insignificant relationship between boards' educational level to ROE. The coefficient of educational level of board is 0.2678 . The table also shows the educational level tstatistic is 0.1824 with the significant of 0.8553 . Therefore, the hypothesis is not supported. The result is not influenced with prior study which found that board with the educational qualification perform significantly better than who are not (Darmadi, 2011). However, although educational qualification should have to perform better in the firm but it cannot be a good proxy for superior advising or managerial quality. Hence, the diversity for performance of firm can be in other variables such as experiences and skills that obtained outsides schools. 
Next, the hypothesis 4 stated that there is a positive relationship between the boards' experience and firm performance. The coefficient of boards' experiences (EXPR) is 0.0241 . The table also shows the boards' experiences has no a positive relationship between firm performance by ROE which the t-statistic of 0.3387 and the level of significant of 0.7349 . Therefore, the hypothesis is not supported. Besides, it is consistent with the prior study which boards' working experiences have a positive correlation with the firm performance (Duc \& Thuy, 2013). Therefore, experiences of boards are needed for the benefits of shareholders and the management of the firms which can contribute positively to firms' performance. So, it can be concluding that the experience of board members has a positively contribute to the better and efficient of the performance of a firm.

After that, the variable of firm size is use in this research which is there is a relationship towards firm performance in term of ROE. The coefficient for firm size (FSIZE) is 1.5722. The Table 4.5 shows the firm size and ROE has a positive relationship which the t-statistic is 2.5719 and the significance is 0.0103 at the $5 \%$ level of significant. Therefore, the hypothesis is supported. It can be proved by the previous study that found a positive relationship between the firm size and profitability (Babalola, 2013). Furthermore, they found that in Nigeria, firm size is considered as important determinant of the profitability. Besides, firm can increase the level of profits which can help the firm grow faster influence with the size of firms which play an important role for performance of firm. Moreover, the size plays role within the corporate environment towards the grows of conglomerates and multinational corporations in today's global economy.

Lastly hypothesis stated that there is a relationship between firm leverage and firm performance of ROE. The coefficient for firm leverage (FLEV) is -0.5386 . The table reveals that firm leverage has a negative insignificant relationship with ROE which is the t-statistic is -0.9639 and the significant 0.3353 . Therefore, the hypothesis is not accepted. This result is not same as the previous study where the leverage has a significantly negative impact on firm performance when the firm size is low or small (Ibhagui \& Olokoyo, 2018). Furthermore, they found that it will give a negative effect decreasing as a firm grows and threatened when firm size exceeds its estimated level. Besides, most of the companies' capital structure are relies on short term debt and has a low amount of long term debt.

\section{CONCLUSION AND IMPLICATION OF STUDY}

There are several main implications of this study to parties like investors, public, manager as well as the government. First, this study will assist to the investors. The finding in this study shows that the gender is significant to ROE. Based on this study, it can guide the investors to make the wise investment decisions. Besides, it also contributes to a better understanding for investors on how the gender is assist to create value and increase the performance of the firm. Hence, this research can extend and assist public to understand thoroughly the factors that determine the firm performance and provide with substantial information about issues in Malaysia. Next, this study could be used to help managers to gain insight on how to enhance firm performance. By having a vary gender of board directors in the firm, they will be motivated and work harder to increase productivity and increase the firm performance. Besides, this study helps the manager to have a better setting of strategies to develop more effectiveness and efficiency in adapting towards the rapidly changing of business environment. This study also recommends to the managers to monitor the gender, firm size and firm leverage very closely as these factors has an impact on the firm performance. Lastly, this study also provides a useful guide for the regulators such as Bursa Malaysia which is full of rules and regulations of disclosure especially those factors that significantly affect the performance of the firms. It is important to have a vary on idea of decision making, the publics, investors and employees are well protected and treated equally in order to create a transparent capital market. This study also contributes to the government and policy makers to achieve a better outcomes and policies for shareholders of public listed companies.

This research has accomplished its objective to provide the information regarding the extent of understanding towards the firm performance in Malaysia. This study included four independent 
variables which is female board member, board size, boards' educational level and boards' experiences towards the firm performance among the listed companies in Bursa Malaysia. The result shows that among the four independent variables only female has significant with the negative relationship towards ROE. In addition, mostly firms in Malaysia were totally dominated by men and only a few number of female on board. Besides, the range of female in board on these samples is small. Hence, these can be seen where female on board have no power in the companies in Malaysia. Others three variables; board size, experience and educational are not significant either in ROA or ROE. Basically, the board members are mostly male in the companies in Malaysia. Besides that, researcher aim to further contribute to the existing theory determinations of firm performance. Managers, investors and public as well as government will be benefited by enhancing their knowledge towards the firm performance in the annual reports. In views of researcher, the public listed companies in Malaysia are still lack of intention in conduction the firm performance. Therefore, level of Malaysia's company disclosed still left behind compared to international companies. Each company has to aware about the diversity and improved the firm performance. There are still have ways for Malaysia achieve Wawasan 2020 which is emphasize on substantial development in term of rapidly changing in environment, innovations and inventions. 


\section{REFERENCES}

Abdullah, S., Ismail, K., Izah, K. N., \& Nachum, L. (2012). Women on Boards of Malaysian Firms: Impact on Market and Accounting Performance, http://papers.ssrn.com/sol3/papers.cfm?abstract_id=2145007

Adams, R. B., \& Ferreira, D. (2009). Women in the Boardroom and their Impact on Governance and Performance. Journal of Financial Economics, 94(2), 291-309.

Adnan, M. F., Sabli, N., Rashid, M. Z., Hashim, A., Paino, H., \& Abdullah, A. (2016). The Impact of Educational Level of Board of Directors on Firms' Performance. Regional Conference On Science, Technology and Social Sciences (Rcstss 2014),37-48. Doi:10.1007/978-981-101458-1_4.

Arena, C., Cirillo, A., Mussolino, D., Pulcinelli, I., Saggese, S., \& Sarto, F. (2015). Women on Board: Evidence from a Masculine Industry. Corporate Governance, 15(3), 339-356.

Arend, R. J. (2004). The Definition of Strategic Liabilities, and their Impact on Firm Performance. Journal of Management Studies, 41(6), 1003-1027.

Azmi, I. A. G., \& Barrett, M. A. (2013, May). Women on Boards and Company Financial Performance: A Study of Malaysian SMEs. In Proceedings of 3rd Global Accounting, Finance and Economics Conference, Melbourne, Australia.

Babalola, Y.A. (2013). The Effect of Firm Size on Firms' Profitability In Nigeria, Journal of Economics And Sustainable Development, 4(5), 90-94.

Baek, J. S., Kang, J. K., \& Park, K. S. (2004). Corporate Governance and Firm value: Evidence from the Korean Financial Crisis. Journal of Financial Economics, 71(2), 265-313.

Bathula, H. (2008). Board Characteristics and Firm performance: Evidence from New Zealand (Doctoral dissertation, Auckland University of Technology).

Beiner, S., Drobetz, W., Schmid, F., \& Zimmermann, H. (2004). Is Board Size an Independent Corporate Governance Mechanism?. Kyklos, 57(3), 327-356.

Bryant, P., \& Davis, C. (2012). Regulated Change Effects on Boards of Directors: A Look at Agency Theory and Resource Dependency Theory. Academy of Strategic Management Journal, 11(2), $1-136$.

Campbell, K., \& Mínguez-Vera, A. (2008). Gender Diversity in the Boardroom and Firm Financial Performance. Journal of Business Ethics, 83(3), 435-451.

Carlsson, G., \& Karlsson, K. (1970). Age, Cohorts and the Generation of Generations. American Sociological Review, 35(4) 710-718.

Carpenter, M. A., \& Westphal, J. D. (2001). The Strategic Context of External Network Ties: Examining the Impact of Director Appointments on Board Involvement in Strategic Decision Making. Academy of Management Journal, 44(4), 639-660.

Carter, D. A., D'Souza, F., Simkins, B. J., \& Simpson, W. G. (2010). The Gender and Ethnic Diversity of US Boards and Board Committees and Firm Financial Performance. Corporate Governance: An International Review, 18(5), 396-414.

Carter, D. A., Simkins, B. J. \& Simpson, W. G. (2003). Corporate Governance, Board Diversity, and Firm Value. Financial Review, 38(1), 33-53.

Carver, J. (2002). John Carver on Board leadership: Selected Writings from the Creator of the World's Most Provocative and Systematic Governance Model. Jossey-Bass, A Wiley Company.

Chaganti, R., \& Damanpour, F. (1991). Institutional Ownership, Capital Structure, and Firm Performance. Strategic Management Journal, 12(7), 479-491.

Combs, J. G., Russell Crook, T., \& Shook, C. L. (2005). The Dimensionality of Organizational Performance and its Implications for Strategic Management Research. In Research Methodology in Strategy and Management (pp. 259-286). Emerald Group Publishing Limited.

Cox, T. (1994). Cultural Diversity in Organizations: Theory, Research and Practice. Berrett-Koehler Publishers.

Darmadi, S. (2013). Board Members' Education and Firm Performance: Evidence from a Developing Economy. International Journal of Commerce and Management, 23(2), 113-135

De Andres, P., \& Vallelado, E. (2008). Corporate Governance in Banking: The Role of the Board of Directors. Journal of Banking and Finance, 32(12), 2570-2580. 
Duc, V. H., \& Thuy, P. B. G. (2013). Corporate governance and firm's performance: empirical evidence from Vietnam. Journal of Economic Development, (JED, No. 218), 62-77.

Earley, P.C. And Mosakowski, E. (2000). Creating Hybrid Team Cultures: An Empirical Test of Transnational Team Functioning, Academy of Management Journal, 43(1)26-49.

Erhardt, N. L., Werbel, J. D., \& Shrader, C. B. (2003). Board of Director Diversity and Firm Financial Performance. Corporate governance: An International Review, 11(2), 102-111.

Fama, E. F., \& Jensen, M. C. (1983). Separation of Ownership and Control. The Journal of Law and Economics, 26(2), 301-325.

Hambrick, D. C., Cho, T. S., \& Chen, M. J. (1996). The Influence of Top Management Team Heterogeneity on Firms' Competitive Moves. Administrative Science Quarterly, 41(4), 659684.

Hillman, A. J., \& Dalziel, T. (2003). Boards of Directors and Firm Performance: Integrating Agency and Resource Dependence Perspectives. Academy of Management Review, 28(3), 383-396.

Hilmer, F. G. (1998). Strictly Boardroom (2nd Edition). Melbourne: Information Australia

Hurst, D.K., Rust, J.C., And White, R.E. (1989). Top Management Teams and Organizational Renewal, Strategic Management Journal, 10(1), 87-105

Ibhagui, O. W., \& Olokoyo, F. O. (2018). Leverage and Firm Performance: New Evidence On the Role of Firm Size. The North American Journal of Economics and Finance. Doi:10.1016/J.Najef.2018.02.002.

Ibhagui, O. W., \& Olokoyo, F. O. (2018). Leverage and Firm Performance: New Evidence on the Role of Firm Size. The North American Journal of Economics and Finance, 45, 57-82.

Jackson, S. E., Joshi, A., \& Erhardt, N. L. (2003). Recent Research on Team and Organizational Diversity: SWOT Analysis and Implications. Journal of Management, 29(6), 801-830.

Jensen, M. C. (1993). The Modern Industrial Revolution, Exit and The Failure of Internal Control Systems. Journal of Finance, 48(3), 831-880.

Jianakoplos, N.A., Bernasek, A. (1998). Are Women More Risk Averse?, Economic Inquiry, 36(4), 620-630.

Julizaerma, M., \& Sori, Z. M. (2012). Gender Diversity in the Boardroom and Firm Performance of Malaysian Public Listed Companies. Procedia - Social and Behavioral Sciences,65, 10771085. Doi:10.1016/J.Sbspro.2012.11.374.

Kahn, A. E. (2002), 'Defining a Diversity Initiative', Inside Supply Management (December), 8-9.

Lee, J. (2009). Does Size Matter in Firm Performance? Evidence from US Public Firms. International Journal of the Economics of Business, 16(2), 189-203.

Levrau, A., \& Van den Berghe, L. A. (2007). Corporate Governance and Board Effectiveness: Beyond Formalism. ICFAI Journal of Corporate Governance, 6(4), 58-85.

Lipton, M., \& Lorsch, J. W. (1992). A Modest Proposal for Improved Corporate Governance. Business Lawyer, 48(1), 59-77.

Lückerath-Rovers, M. (2013). Women on Boards and Firm Performance. Journal of Management \& Governance, 17(2), 491-509.

Maran, M., \& Indraah, K. (2009).Ethnicity and Gender Diversity in Boards of Directors and Their Relevance to Financial Performance of Malaysian Companies. Journal of Sustainable Development, 2(3), 139-148.

Mincer, J. (1958). Investment in Human Capital and Personal Income Distribution. Journal of Political Economy, 66(4), 281-302.

Muth, M. and Donaldson, L. (1998) Stewardship Theory and Board Structure: A Contingency Approach. Corporate Governance: An International Review, 6 (1), 2-28.

Ng, S. H., Teh, B. H., Ong, T. S., \& Soh, W. N. (2016). The Relationship between Board Characteristics and Firm Financial Performance in Malaysia. Corporate Ownership and Control,14(1). Doi:10.22495/Cocv14i1c1p9.

Pfeffer, J. (1972). Size and Composition of Corporate Boards of Directors: The Organization and its Environment. Administrative Science Quarterly, 17(2), 218-228

Pfeffer, J., \& Salancik, G. (1978). The External Control of Organizations: A Resource-Dependence Perspective. New York: Harper \& Row.

Phan, P. H., Lee, S. H., \& Lau, S. C. (2003). The Performance Impact of Interlocking Directorates: The Case of Singapore. Journal of Managerial Issues, 15(3), 338-352. 
Rummel, R. J. (1976). Understanding Correlation. Honolulu: Department of Political Science, University of Hawaii.

Securities Commission Malaysia (2011). Corporate Governance Blueprint 2011. Kuala Lumpur: Securities Commission Malaysia.

Shrader, C. B., Blackburn, V. B., \& Iles, P. (1997). Women in Management and Firm Financial Performance: An Exploratory Study. Journal of Managerial Issues, 9(3), 355-372.

Shukeri, S.N., Ong, W.S., Shaari, M. S., 2012. Does Board of Director's Characteristics Affect Firm Performance? Evidence from Malaysian Public Listed Companies. International Business Research, 5(9), 120-127.

Taljaard, C. C., Ward, M. J., \& Muller, C. J. (2015). Board Diversity and Financial Performance: A Graphical Time-series Approach. South African Journal of Economic and Management Sciences, 18(3), 425-447.

Topal, Y., \& Dogan, M. (2014). Impact of board size on financial performance: The case of BIST manufacturing industry. International Journal of Business Management and Economic Research, 5(4), 74-79.

Wan Yusoff, W.F. (2010). Characteristics of Board Directors and Board Effectiveness: A Study of Malaysian Public Listed Companies. Unpublished PhD Thesis, University of Victoria, Australia.

Wegge, J., Roth, C., Neubach, B., Schmidt, K. H., \& Kanfer, R. (2008). Age and Gender Diversity as Determinants of Performance and Health in a Public Organization: the Role of Task Complexity and Group Size. Journal of Applied Psychology, 93(6), 1301-1313.

Yermack, D. (1996). Higher Market Valuation of Companies with a Small Board of Directors. Journal of Financial Economics, 40(2), 185-211.

Corresponding Author: Mohd Waliuddin Mohd Razali can be contacted at mrmwaliuddin@unimas.my 